\title{
Employee engagement in continuous improvement of processes
}

Ph.D. Renata Brajer-Marczak Wroclaw University of Economics Department of Business Processes Management

\section{Introduction}

The recently growing importance of the focus on processes is based on the need to initiate improvement activities. It is stressed that changes in processes should occur continuously in response to constant changes occurring in the environment of an organisation, particularly in the requirements of its customers and even be ahead of them, as long as it is possible. The literature on the subject includes opinions suggesting that organisations seek opportunities to distinguish themselves with the ability of continuous improvement of processes, which in turn corresponds to extraction and support of employee commitment in continuous improvement of processes. The purpose of the study is presentation of the essence of the problems related to building employee commitment in continuous improvement of processes. Based on the subject literature the existing possibilities of extracting and sustaining it have been shown. Before that, elaborations had been made on the concept of continuous improvement of processes by setting it against the background of contemporary trends 
in management. The paper also presents "employee engagement", taking account of its ambiguity and multidimensionality.

\section{Improvement of processes in the literature on the subject}

Processes implemented by enterprises are currently recognised as a resource of strategic nature, while the quickness and the effectiveness of their improvement has become an element of competition or distinguishing oneself on the market. Using those processes it can be determined how organisations function. According to R. Tregear (Tregear 2014, p. 3) "if managers do not care for processes, it is as if they did not thinking of business at all, since a company is as good for the customer as much it implements its processes efficiently". As a result of accepted organisational solutions in accordance with the idea of continuous improvement of the management system (Continuous Improvement Management) enterprises should be capable of improving the operations they conduct primarily by improving implemented processes, since, as E. Skrzypek and M. Hofman (Skrzypek, Hofman 2010, p. 30) claim "the problem of contemporary organisations is not the quality of their products or services, but the quality level of the processes that create these products or services. Therefore, it can be assumed that the quality of products and services is a derivative of the quality of processes". Improvement may include actions lasting continuously, e.g. constant monitoring of a process aimed at shortening the duration of performed operations as well as periodic improvement projects (Shani, Lindberg 2001, p. 41). An organisation focused on improvement of processes becomes a learning organisation, in which all participants learn responsibility for all the sequences of logically arranged activities. It is believed that only such an organisation is able to respond to constantly changing customer requirements and expectations. Improvement of processes cannot be regarded as a one-time project, since creation of value requires pressure on processes spread over time (Smart, Maddern, Maul 2009, p. 26). R. Smith (Smith 2007, p. 24) claims that "excellence in implementation of processes may be a factor determining an enterprise's future by helping it acquire new customers and markets".

Continuous improvement is defined as making systematic efforts aimed at finding and using new ways of conduct to actively and repeatedly take initiatives to introduce changes (Anand, Ward, Tatikonda, Schilling 2009, p. 444). The essence of continuous improvement of processes consists in a permanent search for the possibilities of improvement in daily operations associated with implemented processes with observance of the assumed 
problem solving methodology and using the experience resulting from made mistakes (Grajewski 2007, p. 104).

This notion is also defined as a situation in an organisation in which all its employees constantly search for opportunities to eliminate the causes of imperfections in the functioning of the organisation (Al-jawazneh, Smadi 2011, p. 234). It involves all employees, while improvement initiatives, usually regarding the fragments of more filed processes, are developed at workplaces. The object of improvement also covers inter-departmental and inter-organisational processes, while the improvement itself in many cases is implemented in teams of employees from various branches, sections or departments of the organisation (Becker 2008, p. 20). This way the full improvement potential existing in an organisation's processes, also in those going beyond its boundaries, implemented in cooperation with other enterprises, can be released. Continuous improvement of processes, as opposed to radical initiatives, involves using the capabilities found in currently held potential of an organisation in an evolutionary manner. Continuous improvement is also one of the principles of quality management systems based on ISO 9000 series of standards ${ }^{1}$. However, the English version of ISO 9000 does not use the known term continuous improvement, but continual improvement. The difference in the terms concerns the fact the word continuous means that the activities are implemented at all times in a continuous manner, while the word continual means that the activities are taken often, in cycles, but there are pauses between them (www.gembapantarei.com). E. Deming (http://asq.org) would also distinguish the abovementioned terms. He claimed that the term continual improvement is a broader term which refers to general improvement processes and covers "discontinuous" improvements in different areas of an organisation. On the contrary, continuous improvement it is a subset of continual improvement in which special stress is put more linear, incremental improvement within the existing processes. Some practitioners of management associate the term with methods based on statistical process control. Additionally, the literature on the subject includes a view according to which continuous improvement applies to a situation where introduced changes have a considerably greater (sometimes radical) impact on functioning of a given organisation than in the case of

1 We can find a reference to this principle in three of them, i.e. ISO 9000 - Quality management systems. Basics and terminology, ISO 9001 - quality management systems. Requirements and ISO 9004 - Management focused on permanent success of an organisation. Approach using quality management (www.pkn.pl). 
continual improvement (Govender 2008, p. 313). On the other hand, in subsection 9.2 of standard ISO 9004 entitled Improvement it is stated that "improving actions may include the scope ranging from minor improvements continuously introduced at the workplace up to significant improvement of the entire organisation" (PNEN ISO 9004, p. 41). Currently we may indicate a group of practitioners and scholars who treat the Total Quality Management (TQM) method as a strategy of continuous improvement of an organisation's activities within the area of its processes. They believe a well-designed and implemented quality system according to ISO 9001 makes the implementation of the TQM idea considerably easier(Lisiecka 2013, p. 21). Practitioners and scholars on the BPTrends forum have also ${ }^{2}$ begun discussing continuous, constant improvement of processes. A. Sharp suggested that for practical reasons" "regular improvement" will be a more suitable term than "continuous improvement" (Tregear 2014, p. 2). He argues in favour of his suggestion by stating that the emphasis from continuous and uninterrupted introduction of improvements should be shifted towards "well thought-out and carefully introduced improvement of processes" along with a detailed analysis of its effects.

\section{Importance of the notion of employee engagement}

Both practitioners and scholars have yet to develop a uniform, clear definition of the term employee commitment. The theoretical grounds for the elaborations on employee commitment in work have been developed by psychologists. One of the first scholars who directly delved into the issues of employee commitment was psychologist William, A. Kahn (1990), who believed commitment was a multi-dimensional term. He claimed that employees can be involved in their work emotionally, cognitively and physically, given that they can be committed only in one of those three dimensions (Mrówka 2012, p. 7). The literature in the field of management employee commitment is defined as "a positive doublesided relationship between an employee and their organisation in which both parties respect their mutual needs and support each other in order to satisfy them. Thanks to that, employees and organisations achieve additional profits" (Daniel 2004, p. 1). Another definition states that "it is a positive, a state of mind

2 BPTrends is an association grouping 15000 members; its websites are used by Business Process Management practitioners and scholars to make available studies and opinions about the trends, the directions and the best practices with regard to all aspects of business process management.

91

RENATA BRAJER-MARCZAK 
satisfying one's desires associated with work that manifests itself by vigour, devotion, receptivity (Schaufeli et al. 2004, p. 74). Commitment is a complex and continuous way of discovery of the methods of increasing employee efficiency. It is a part of employee behaviour and is expressed in the willingness to work for the benefit of an organisation. A committed employee is a person who focuses on their work, has an enthusiastic attitude towards performing it and achieves or surpasses the business objectives requested from them acting to the best interest of their company. In publications written in English there are several terms pertaining to employee commitment. Terms such as employee engagement, job involvement, commitment to organisation appear. Some authors regard those terms as almost identical (Falcone 2006, Mc Cashland 1999, Miles 2001, Harter et al. 2002 after: Mrówka 2010, p.7). On the other hand, W. A. Kahn (1990) differentiates them from one another by claiming that "employee engagement" is a more term complex than the other ones. It is also difficult to clearly ascertain whether employee commitment is a result creation in proper working conditions (Mc Cashland 1999), a phenomenon dependent on the superiors, relationships with them (Blizzard 2003) or something which is associated with a given employee's personality (Harter et al. 2002). O'Malley states that based on the review of the literature on the subject we can point to five major factors that contribute to the development of employee commitment. These include: Those are affiliation, association, moral, affective and structural factors ( $\mathrm{O}^{\prime}$ Malley 2000, p. 45). Many authors also point out that the important issue in building employee commitment is how they perceive the ethos and the value of an organisation, the clarity of the expectations to be met by them, receiving regular feedback about the assessment of the work they perform, dialogue with their superiors, positive impact of the superiors, a high probability of getting a bonus for exceptional results and promotion opportunities (Ryan, Deci 2000). A common element of particular opinions about employee commitment is the conclusion that it eventually leads to the release of some energy in an employee, which makes him or her work in a manner exceeding the minimum, standard requirements, given that it happens because of the employee's own will. Such energy can be released for some time and is not a short-term impulse (Mrówka 2010, p. 8).

\section{Engagement in continuous improvement of processes}

Many authors argue that organisations currently compete not as much as in terms of economic processes as the capacity to improve them continuously (Teece 2007; Porter 2001, p. 192). This capacity is conditioned by a number of factors which 
create (support) or reduce (inhibit) it. One of such factors is undoubtedly employee engagement in improvement of processes. They can be define as a philosophy of management and leadership focused on extraction of people's activity in terms of continuous improvement of processes associated with successes at their workplace (Heathfield 2014). Continuous improvement of processes assumes incorporation of cognisant and creative employees in operations aimed at systematic improvement of processes. In this case participatory management is utilised, while the majority of the conceptual work concerning the improvements and changes introduced to a process is done by the participants of said processes. The principal issue is determination of the conditions which will inspire and encourage the implementers of processes to produce concepts concerning potential improvements of the processes (Skrzypek, Hofman 2010, p. 134). Improvement of processes is based on permanent "uncovering" of problems, their causes and finding the possibility of limiting them (Tregear 2014, p. 1). It is, however, necessary to bear in mind that the more improvements is introduced the more difficult it is to find problems and extract employee engagement. Therefore, continuous improvement of processes requires appropriate thinking, teamwork, support from the managers and an organisational culture which values seeking the opportunities to introduce changes, while finding the problem should be a reason for celebration by itself. It is difficult to envision in many organisations, thus the most often celebrated occasion is solving a specific problem. The idea of continuous improvement of processes requires each employee to develop their analytical skills and conceptual thinking. If an organisation is to have a true continuous improvement program, it must feature individual, team and organisational thinking that all its employees knowingly seek opportunities of process-related improvements. Therefore, they must have the time, the resources, the incentives and the feedback, particularly useful to search for problems, and hence supporting the improvement of processes. It is worth noting that on the one hand searching for problems lies in the nature of many employees, while on the other hand, this is usually not appreciated by many managers. The more so, searching for improvement opportunities in a process which seems not to manifest any symptoms of disturbances may be perceived as an unnecessary action, unnecessarily disturbing the status quo. Shigeo Shingo, co-founder of the Toyota Production System, saw substantial sources of improvement of processes in the way of thinking, in "positively" disposed, problem-seeking employees (Schingo 1989 after: (Tregear 2014 p. 4). However it is worth emphasising that this is not possible without a proper organisational atmosphere and objectives determined at the highest management levels. 
The more so that continuous improvement relates not only to single processes, as managers strongly care about improvements in the process space. Currently, seeking problems in processes exceeding traditional functions and even going beyond an organisation's boundaries is not a part of business everyday practice. Apart from typical problems, associated with e.g. "burnout", feeling tired of continuous searches for opportunities of changes, we may encounter new problems related to the lack of competences with regard to the stages of implementation of a given process in other departments, branches etc. Most often such rights are held by process managers and the higher management level.

Not all organisations feature a self-propelling mechanism of improvement of processes. In connection with the above, at this point it is worth referring to practical experience concerning generation of a culture of improvement and extraction of employee engagement. Due to the multidimensionality of the phenomenon there are many proposals in this respect. For instance, R. Tregear proposes preparing a non-complicated system of submission of ideas of changes and their quick assessment, summoning short sessions at workplaces in which the employees may identify and discuss the problematic areas and proposals of improvements, public praises, especially of ideas put into effect with good results, publishing a summary indicator of the effects of improvements of process-related improvements (Tregear 2014, p. 4). The research of the Institute for Employment Studies (IES) shows that the most important factors creating employee engagement include: involving employees in decision making, a high degree of employee freedom to express opinions, ideas, reporting ideas, a high degree of managerial attention to employee initiatives, appreciation for contribution of employees, employees being able to define their work, a degree to which an organisation cares about its employees' comfort and mood (Robinson et al. 2004). The instructions in this field can be also found among the TQM assumptions, which mention that:

- employees have the impression that their company is a friendly working environment ruled by the principles of partnership, cooperation, trust and openness,

- all employees are involved in the continuous improvement process, their activity in this respect, though formally covered by the scope of their professional responsibilities, results mainly from the internal sense of obligation towards the customers and the company,

- all its employees have sufficient knowledge and skills associated with continuous improvement of processes, 
- employees are suggested constant training in "improvement of the ways of improvement" (Blikle 2014, p. 388).

Assuming that each employee shows his or her desire for creative action to some extent, including searching for problems in implemented processes and suggesting the opportunities for improvement, it appears that we should building engagement in improvement of processes refer to two phases: extraction and support of engagement. Table 1 includes a suggestion activities that can be introduced in organisations.

Table 1. Characteristics of exemplary actions related to the creation of commitment to continuous improvement of processes

\begin{tabular}{|c|c|c|c|}
\hline Action & Characteristics & $\begin{array}{l}\text { Extraction of } \\
\text { engagement }\end{array}$ & $\begin{array}{c}\text { Support of } \\
\text { engagement }\end{array}$ \\
\hline Leadership & $\begin{array}{l}\text { Continuous improvement is rooted in a } \\
\text { company's strategy of operations, when the } \\
\text { managers give examples of their engagement } \\
\text { in improving the management system }\end{array}$ & $\mathrm{x}$ & $\mathrm{x}$ \\
\hline $\begin{array}{l}\text { Definition of } \\
\text { objectives of } \\
\text { improvement of } \\
\text { processes }\end{array}$ & $\begin{array}{l}\text { All employees are focused in their } \\
\text { improvement activities on customer } \\
\text { needs and expectations, the objectives of } \\
\text { improvement of processes correspond to the } \\
\text { strategic objectives of a given company and } \\
\text { are known to the employees }\end{array}$ & $\mathrm{x}$ & $x$ \\
\hline $\begin{array}{l}\text { Support for the } \\
\text { idea of continuous } \\
\text { improvement of } \\
\text { processes }\end{array}$ & $\begin{array}{l}\text { The managers express respect for the } \\
\text { initiatives of the people involved in } \\
\text { improvement activities, introduce } \\
\text { structural solutions and develop supporting } \\
\text { communication }\end{array}$ & & $\mathrm{x}$ \\
\hline Trust for employees & $\begin{array}{l}\text { Faith in the skills and good intentions of } \\
\text { employees, giving freedom in action agreed } \\
\text { within the boundaries set by the objectives of } \\
\text { a given process }\end{array}$ & $x$ & $x$ \\
\hline Training programs & $\begin{array}{l}\text { Through the offered the subject matter of } \\
\text { training courses the employees are able } \\
\text { to acquire and develop analytical and } \\
\text { conceptual skills }\end{array}$ & & $x$ \\
\hline Sharing knowledge & $\begin{array}{l}\text { Creation of commonly available knowledge } \\
\text { bases containing information about } \\
\text { implemented improvement projects, free } \\
\text { flow of information on good practices in this } \\
\text { respect }\end{array}$ & & $x$ \\
\hline
\end{tabular}




\begin{tabular}{|c|c|c|c|}
\hline $\begin{array}{l}\text { Provision of } \\
\text { resources needed } \\
\text { in improvement of } \\
\text { processes }\end{array}$ & $\begin{array}{l}\text { As part of a defined scope of tasks } \\
\text { providing time for seeking opportunities } \\
\text { of improvement of processes, access to } \\
\text { informational resources and necessary } \\
\text { knowledge }\end{array}$ & & $x$ \\
\hline $\begin{array}{l}\text { Proper assignment } \\
\text { of tasks }\end{array}$ & $\begin{array}{l}\text { Regarding employee obligations apart } \\
\text { from the tasks assigned to a given position, } \\
\text { placement of improvement activities }\end{array}$ & $x$ & $x$ \\
\hline Provision of feedback & $\begin{array}{l}\text { The individuals introducing improvements } \\
\text { in processes receive information on their } \\
\text { effects on a current basis; this motivates } \\
\text { the employees and fosters their } \\
\text { development }\end{array}$ & & $x$ \\
\hline Autonomy in action & $\begin{array}{l}\text { The employees are free to decide about } \\
\text { the sequence they perform tasks, are } \\
\text { aware of the objectives set before them } \\
\text { and treat improvement initiatives as } \\
\text { a priority }\end{array}$ & $x$ & $x$ \\
\hline Tolerance of failures & $\begin{array}{l}\text { Acceptance for not always effective proposals } \\
\text { of improving processes and the ability to } \\
\text { return to the prior situation as well as making } \\
\text { a further search for problems and the ways to } \\
\text { eliminate them possible }\end{array}$ & & $x$ \\
\hline $\begin{array}{l}\text { Acknowledgment for } \\
\text { accomplishments }\end{array}$ & $\begin{array}{l}\text { Showing appreciation for undertaken } \\
\text { improvement efforts in the form of formal } \\
\text { and informal communication, providing } \\
\text { prizes for achievements in this respect }\end{array}$ & $x$ & $x$ \\
\hline $\begin{array}{l}\text { Actual ability } \\
\text { to introduce } \\
\text { improvements in a } \\
\text { process }\end{array}$ & $\begin{array}{l}\text { The suggested improvements can be actually } \\
\text { introduced to practice and the effects they } \\
\text { bring can be observed }\end{array}$ & & $x$ \\
\hline $\begin{array}{l}\text { Unlimited } \\
\text { cooperation of } \\
\text { process participants }\end{array}$ & $\begin{array}{l}\text { Requires understanding of the actual needs } \\
\text { of the end users of a given process as well } \\
\text { as the workflow throughout the entire } \\
\text { process. This creation of an environment } \\
\text { and a management structure making actual } \\
\text { teamwork possible, the success of which is } \\
\text { based on exchange of knowledge, } \\
\text { experience and particularly on the } \\
\text { ability to cooperate and ensure good } \\
\text { communication }\end{array}$ & $x$ & $x$ \\
\hline
\end{tabular}




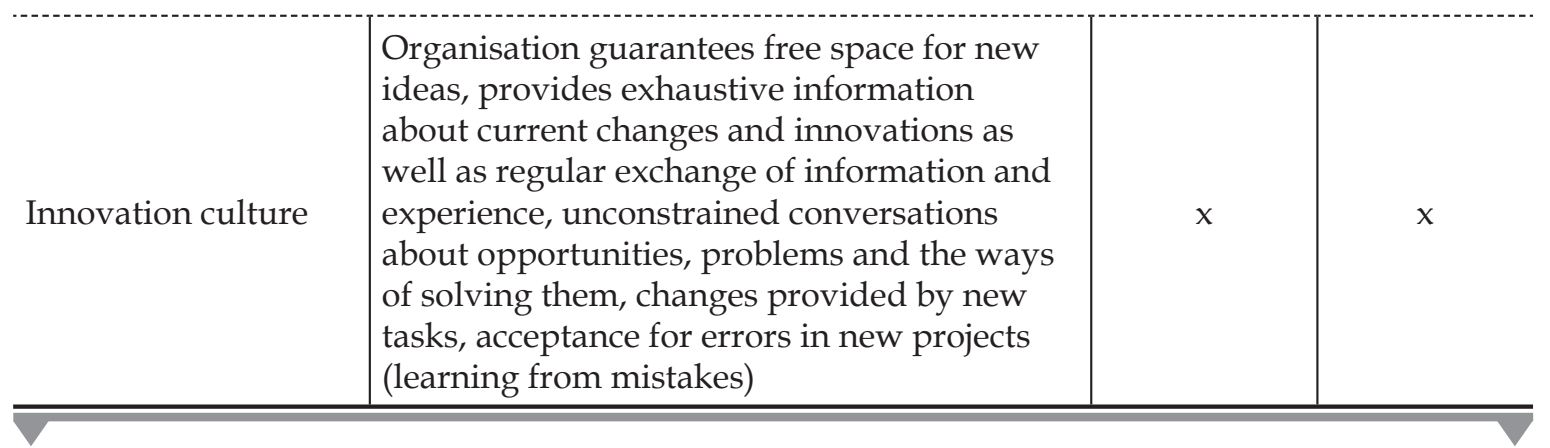

Source: own study based on among others: Mrówka R. (2010), Pojęcie zaangażowania pracowników we współczesnych naukach ekonomicznych i praktyce gospodarczej,

w: R. Bartkowiak, J. Ostaszewski (red.) Nauki ekonomiczne w świetle nowych wyzwań gospodarczych, Oficyna Wydawnicza SGH, Warszawa, p. $405-416$, Osbert-Pociecha G. (2011), Procesowość jako sposób kreowania i osiągania elastyczności organizacji, w: S. Nowosielski (red.), Podejście procesowe w organizacjach, Wydawnictwo Uniwersytetu Ekonomicznego we Wrocławiu, Wrocław, p.117-126, Brajer-Marczak R. (2014), Aspekty kulturowe $w$ przedsiębiorstwie zorientowanym w zarządzaniu na procesy, w: Nowe kierunki w zarządzaniu. Wiodące orientacje, Wydawnictwo Uniwersytetu Ekonomicznego we Wrocławiu, Wrocław, p. 143-154

M. Urbaniak (Urbaniak 2010, p. 45) argues that organisations that put a particular emphasis on the process of personnel management, especially on raising personnel qualifications by investing in its development, achieve higher employee engagement in improvement of processes, efficiently affecting their attitude regarding identification of problems and problem solving as well as reporting improvement initiatives. While being effective in the operational aspect comes down to being able to act more precisely, performing all than one has been doing so far reliably, then achieving effectiveness in improvement of processes involves acting differently, by basing one's actions on distinctive, unique competences, that is showing the ability to apply new knowledge, new abilities and skills in handling new requirements and/or unrevealed customer wishes (Lisiecka 2012, p. 106-107). An interesting trend, recently observed in practice is creation of intra-organisational communities concentrated around particular processes which, being similar in form to known social networking websites, enable publication of comments, discussing problems and initiating improvement projects (Report: Good Practice...2010, p. 20). They are a place fostering the exchange of experiences, mutual inspirations, but also presentation of effects and accomplishments of employees. Continuous improvement of processes is also or even primarily determined by meeting the conditions of temporary and financial disposal (Nowosielski 2014, p. 45). Many employees 
feel "overwhelmed" by their daily responsibilities. In such a situation appeals of the top management to increase the efforts towards improvement of processes fail, since the employees simply lack the time to handle tasks other than those they are performing at the moment. A similar results happens even when the employees have free time, but the management assigns a higher priority to professional obligations, treating improvement actions not as work, but as additional activities which can be taken care of when there is enough time for them ("first the work, then the improvement"). A similar situation occurs in the event of absence of funds for conducting improvement works. If they are insufficient, many projects will not be implemented. In addition, special attention should be paid to the need for introduction of an interactive management style, which is opposite to the authoritarian-directive style (Nowosielski 2014, p. 46).

\section{Conclusion}

Currently, many organisations highlight the problem of engagement of their employees to work. The report entitled "State of the Global Workplace" drawn up by the Gallup Institute (Gazeta Wyborcza 26 Mar 2014) states that only 13\% of employees worldwide are committed to their work. They are known as Engaged. These are employees who derive joy from what they do, introduce innovations and develop enterprises. Most of them employees are uncommitted - Not Engaged - $63 \%$ - this is personnel that does not put significant effort in their work, usually simply waiting for the work day to be over. The remaining part - $24 \%$ consists of those who contest work - Actively Disengaged. These are employees displeased with work who devote the majority of their time to manifest their dissatisfaction and question the accomplishments of others. A review of various literature sources suggests that employee engagement in continuous improvement of processes does not significantly differ from the situation presented above. In practice, organisations insufficiently develop their internal abilities (including employee engagement) to continuous improvement of processes, therefore this improvement occurs too slowly and applies, first of all, to single processes, while the focus is put on simple operations, removal of excessive ballast (cutting costs) instead of creating added value. Among the mentioned problems we can indicate the opinion of managers that employee engagement does not have to be built or supported, ignoring fact that seeking a proposal of changes is a "long road" requiring patience and support, formalisation of assessment of new ideas, which effectively discourages employees undertake any activities in this respect, expressing fear of making mistakes, seeking improvements when the necessity 
for their introduction has already appeared, which is inconsistent with the idea of continuous improvement (Koulopulos 2010, p. 9). A fairly weak emphasis is put also on the strengths of active participation in improvement of processes, which include: the opportunity to present one's own point of view, suggesting changes, and in connection with the above, increasing the satisfaction from the performed work or growth in trust in one's own capabilities. In addition, the matter is complicated by the fact that continuous improvement of processes is not the issue of individual employees, but in many cases is done by teams of employees coming from different organisational departments. Because of this not only the knowledge and the creativity of the employees are being put to use, but the success of the process team is based on proper transfer and exchange of knowledge and particularly on the abilities of its members in the field of communication and cooperation (Gaitanides 2012, p. 193). In such a situation we can say that "collective engagement " exists within a given group of employees, where there is a need to influence a team of people. It appears that the so-called change agents , who redirect an organisation to "process tracks" (Sieniawska 2014, p.1), should have much to offer in this respect and be the source of inspiration for the employees. They show the employees personal benefits from a different style of work, negotiate, convince that initiating improvement activities is justified.

It should be emphasised that analysing the problems related to creation of employee engagement in improvement of processes is cognitively interesting, but also useful in practice, especially that, as indicated in the first part of this study, without knowledge and skills associated with improvement of processes it is currently difficult to compete in a variable market environment. The author of the study is aware that the deliberations presented in the article are not exhaustive in view of the chosen subject. The conducted elaborations made it possible to explore the subject, however, they require confirmation done in the course of empirical research.

\section{Summary}

Employee engagement in continuous improvement of processes The article, which is supposed to present the essence of the problems related to building employee engagement in continuous improvement of processes, highlights the existing possibilities of its extraction and sustaining. The paper has pointed out that the subject matter associated with building employee engagement in improvement of processes is cognitively interesting, but also useful in practice, especially that, as indicated in the first part 
of this study, without any knowledge and skills associated with improvement of processes it is currently difficult to compete in a variable market environment. The article has also elaborated on the concept of continuous improvement of processes by setting it against the background of contemporary trends in management. It has presented the term "employee engagement ", taking account of its ambiguity and multidimensionality. The article serves as a review based on the studies subject literature.

Key words: process, continuous improvement of processes, engagement to improvement of processes.

\section{Streszczenie}

\section{Zaangażowanie pracowników w ciągłe doskonalenie procesów}

$\mathrm{W}$ artykule, którego celem jest prezentacja istoty problemów związanych $\mathrm{z}$ budowaniem zaangażowania pracowników $\mathrm{w}$ ciągłe doskonalenie procesów wskazano na istniejące możliwości jej wydobywania i podtrzymywania. Zwrócono uwage na to, że tematyka związana $\mathrm{z}$ budowaniem zaangażowania pracowników $\mathrm{W}$ doskonalenie procesów jest interesująca poznawczo, ale też przydatna $\mathrm{w}$ praktyce, szczególnie, że jak wskazano $\mathrm{w}$ pierwszej części niniejszego opracowania bez wiedzy i umiejętności doskonalenia procesów trudno obecnie rywalizować $\mathrm{w}$ zmiennym otoczeniu rynkowym. $\mathrm{W}$ artykule przeprowadzono również rozważania na temat koncepcji ciągłego doskonalenia procesów, osadzając je na tle współczesnych trendów w zarządzaniu. Zaprezentowano pojęcie "zaangażowanie pracowników", zwracając uwagę na jego wieloznaczność i wielowymiarowość. Artykuł ma charakter przeglądowy, bazuje na literaturze przedmiotu.

\section{Słowa}

kluczowe: proces, ciagłe doskonalenie procesów, zaangażowanie w doskonalenie procesów.

\section{References:}

1. Al.-jawazneh B., Smadi Z. A. (2011), The behavioral pattern of continuous improvement at the manufacturing companies in Al-Hassan Industrial Estate, 
"European Journal of Social Sciences", No 2/19, p. 233-250, http:// connection.ebscohost.com (3.08.2014 - data dostępu).

2. Anand G., Ward P.T., Tatikonda M.V., Schilling D.A. (2009), Dynamic capabilities through continuous improvement infrastructure, "Journal of Operations Management" No 27, p. 444, https:/ / fisher.osu.edu (5.08.2014 - data dostępu).

3. Becker T. (2008), Prozesse in Produktion und Supply Chain Optimieren, Springer eBook.

4. Blikle A.J. (2014), Doktryna jakości, Rzecz o skutecznym zarządzaniu, www. moznainaczej.com.pl.

5. Brajer-Marczak R. (2014), Aspekty kulturowe w przedsiębiorstwie zorientowanym w zarzadzaniu na procesy, w: Nowe kierunki w zarzadzaniu. Wiodace orientacje, Wydawnictwo Uniwersytetu Ekonomicznego we Wrocławiu, Wrocław.

6. Daniel T. (2004), Engagement policies boost pre-tax profits at Nationwide, "Personnel Today", 2 November.

7. Gaitanides M. (2012), Prozessorganization. Entwicklung, Ansätze und Program des Managements von Geschäftsprozessen, Verlag Franz Vahlen, Múnchen.

8. Govender R. (2008), Continual improvement within South African abattoir Hygiene Management Systems, "Total Quality Management Journal" 4/24, s. 310-325, http:/ / www.emeraldinsight.com (6.08.2014 data dostępu).

9. Grajewski P. (2007), Organizacja procesowa, PWE, Warszawa.

10. Harter J.K., Schmidt F.L., Hayes T.L. (2002), Business-unit-level relationship between employee satisfaction, employee engagement, and business outcomes: a meta: analysis, "Journal of Applied Psychology 87 (2), p. 268-279, http:/ / eds.b.ebscohost.com (5.08.2014 - data dostępu).

11. Heathfield S.M. (2014), What people want from work: Motivation, www. humanresources.about.com.

12. Kahn W.A. (1990), Psychological Conditions of Personal Engagement and Disengagement at Work, Academy of Management Journal 33 (4) http:// www.jstor.org/stable (2.08.2014 - data dostępu).

13. Koulopulos T. (2010), How to kill an idea in 10 easy steps, "The Journal for Quality and Participation", No 1, p. 8-10 http://eds.a.ebscohost.com (4.08.2014 - data dostępu).

14. Lisiecka K. (2013), Systemy zarządzania jakościa produktów. Metody analizy $i$ oceny, Wydawnictwo Uniwersytetu Ekonomicznego w Katowicach, Katowice.

15. Mc Cashland C.R. (1999), Core Components of the service climate: Linkages to customer satisfaction and profitability, Dissertation Abstracts International US: Univ Microfilms International 60 (12-A). 
16. Mc Cormack K., Johnson B. (2001), Business process orientation, supply chain management and the e-corporation, IIE Solutions, October, p. 33-75 http:// eds.b.ebscohost.com (3.08.2014 - data dostępu).

17. Mrówka R. (2010), Pojęcie zaangażowania pracowników we wspótczesnych naukach ekonomicznych i praktyce gospodarczej, w: R. Bartkowiak, J. Ostaszewski (red.) Nauki ekonomiczne w świetle nowych wyzwań gospodarczych, Oficyna Wydawnicza SGH, Warszawa, s. 405-416.

18. Nowosielski S. (2010), Integracja zarzadzania organizacją. Podejście procesowe, w: H. Jagoda, J. Lichtarski (red.) Kierunki i dylematy rozwoju nauki i praktyki zarządzania przedsiębiorstwem, Wydawnictwo Uniwersytetu Ekonomicznego we Wrocławiu, Wrocław.

19. Nowosielski S. (2014), Ciągłe doskonalenie procesów w organizacji. Możliwości $i$ ograniczenia, w: Nowe kierunki w zarzadzaniu. Wiodace orientacje, Wydawnictwo Uniwersytetu Ekonomicznego we Wrocławiu, Wrocław.

20. O'Malley M. (2000), Creating Commitment: How to Attract and Retain Talented Employees by Bulding Relationships That Last, John Wiley\&Sons, San Francisco.

21. Osbert-Pociecha G. (2011), Procesowość jako sposób kreowania i osiagania elastyczności organizacji, w: S. Nowosielski (red.), Podejście procesowe w organizacjach, Wydawnictwo Uniwersytetu Ekonomicznego we Wrocławiu, Wrocław.

22. Porter M. (2001), Porter o konkurencji, PWE, Warszawa.

23. Raport: Dobre praktyki w zarządzaniu procesami biznesowymi, www. procesowcy.pl.

24. Raport: State of the Global Workplace, Gazeta Wyborcza z dn. 26.03.2014.

25. Robinson D., Perryman S., Hayday S. (2004), The drivers of employee engagement, Report 408, Institute for Employment Studies, April http:/ / www.wellbeing4business.co.uk. (2.08.2014 - data dostępu).

26. Rogala P. (2014), Ciagłe doskonalenie jakości według norm ISO serii 9000, w: Nowe kierunki w zarzadzaniu. Wiodace orientacje, Wydawnictwo Uniwersytetu Ekonomicznego we Wrocławiu, Wrocław.

27. Ryan R.M., Deci E.L. (200), Self-Determination Theory and the Facilitation of Intrinsic Motivation, Social Development and Well-Being, "American Psychologist", Vo 55, p. 68-78 http://www.youblisher.com (9.082014 data dostępu).

28. Schaufeli W.B., Bakker A.B. (2004), Job demands, job resources and relationship with burnout and engagement: a muli-sample study, "Journal of Organizational Behaviour", Vol. 25, p. 293-315 http:/ / onlinelibrary.wiley.com (1.08.2014 - data dostępu).

29. Shani A.B., Lindberg P. (2001), Continuous Improvement: Exploring Alternative Organizationale Designs, “Total Quality Management”No 1, p. 41-55 http://eds.a.ebscohost.com (6.08.2014 - data dostępu). 
30. Sieniawska M. (2014), Czy "procesowiec"=agent zmiany?, www.procesowcy. pl (7.08.2014 - data dostępu).

31. Smith R. (2007), Business Process Management and the Balanced Scorecard: Using Processes as Strategic Drivers, John \& Sons, New York.

32. Skrzypek E., Hofman M. (2010), Zarządzanie procesami w przedsiębiorstwie. Identyfikowanie, pomiar, usprawnianie, Wyd. Oficyna a Wolters Kluwer business, Warszawa.

33. Teece D.J. (2007), Explicating dynamic capabilities: the nature and microfoundations of (sustainable) enterprise performance, "Strategic Management Journal", No 28 http:/ / eds.a.ebscohost.com (2.08.2014 data dostępu).

34. Tregaer R. (2014), Continuous problem finding, letter March 2014, http:// bptrends.com (4.08.2014 - data dostępu).

35. Urbaniak M. (2010), Kierunki doskonalenia systemów zarządzania jakościa, Wydawnictwo Uniwersytetu Łódzkiego, Łódź.

36. PN-EN ISO 9004.

37. Strona internetowa: www.pkn.pl (9-08.2014 - data dostępu).

38. Strona internetowa: http:/ / asq.org (7.08.2014 - data dostępu).

39. Strona internetowa: www.gembapantarei.com (6.08.2014 - data dostępu). 